\title{
BENDING MOMENT RESISTANCE OF T-TYPE JOINTS REINFORCED WITH BASALT AND GLASS WOVEN FABRIC MATERIALS
}

\author{
Abdurrahman Karaman ${ }^{1, \$}$ \\ https://orcid.org/0000-0002-5925-7519
}

\begin{abstract}
This study investigated the bending moment resistance of T-type, two-pin dowel joints connected with Scotch pine dowel (Pinus slyvestris), beech dowel (Fagus orientalis), chestnut dowel (Castanea sativa) and oak dowel (Quercus petraea) and reinforced with basalt and glass woven fabric. The tests was carried out to determine the bending moment resistance of dowel joints. As a result of bending test, it was determined that one layer and two surfaces the reinforce with fiber woven fabrics increases the mechanical performance of furniture fasteners according to obtained data from tests conducted on the T-type, two pin dowel joints. The test samples prepared from the oak wooden give the higher moment values than the beech wooden. This study showed that the joining with the oak dowel was $13 \%$ higher than the beech dowel, $32 \%$ the chestnut dowel, and $43 \%$ higher than the Scotch pine dowel (for the bending moment resistance), respectively. According to the bending moment resistance of the samples reinforced by fiber woven fabrics. The highest bending moment resistance value was obtained in the test specimens of reinforced with the basalt woven fabric, the lowest bending moment resistance value was obtained in the test specimens not reinforced (Control). In general, it was determined that the wood species by $3 \%$, wooden dowel species by $43 \%$, and fiber woven fabric types by $72 \%$ have been effects on the results of the bending tests.
\end{abstract}

Keywords: Basalt woven fabric, bending moment resistance, glass woven fabric, two-pin dowel joint, wooden dowel.

\section{INTRODUCTION}

Dowel joints have been one of the most widely used connection in the furniture industry for joining wooden structural members in the furniture (Chen et al. 2018, Hao et al. 2020). The strength and stiffness of these joints are determined by the dowel spacing, the the depth of penetration, wood species, adhesive type, tight fit etc. (Zhang et al. 2003). The resistance of the bending moment or stiffness of the dowel joint was increased by stages with the rising diameter and length of dowel (Chen et al. 2018).

The T-type, two-pin dowel joints strength is affected by a few parameters including the type of adhesive and properties of wood and wood composite materials by used, also a variety of dowel joint process parameters such as dowel spacing, dowel dimension, dowel position and dowel joint geometry configurations (Vassiliou $e t$ al. 2016, Uysal and Haviarova 2018, Záborský et al. 2018, Hao et al. 2020), solid wood and wood based composite used in (Vassiliou et al. 2016, Uysal and Haviarova 2018, Záborský et al. 2018), dowel joint geometry configurations (Vassiliou et al. 2016, Záborský et al. 2018, Hao et al. 2020), rail widths (Zhang et al. 2003), configurations of joints (Yerlikaya and Aktas 2013), different cyclic load (Vassiliou et al. 2016).

Fiber reinforced polymer (FRP) materials include carbon, glass and aramid FRPs and provide advantages over the traditional repair materials in terms of better mechanical and chemical performance and easier constructability (Sim 2001). Basalt-based materials are environmentally friendly and non-hazardous. The current 
production technology for continuous basalt fibres is very similar to that used for E-glass manufacturing. The main difference is that E-glass is made from a complex batch of materials whereas basalt filament is made from melting basalt rock with no other additives and, as a consequence, with an advantage in terms of cost. Their specific mechanical properties are comparable with, or better than, those of E-glass ones. The glass fiber reinforce polymer (GFRP) material value of density, elasticity modulus, tensile strength and elongation to fracture were 2,6 g/ $\mathrm{cm}^{3}, 76 \mathrm{GPa}, 2,0 \mathrm{GPa}$, and 2,5\%, respectively (Fiore et al. 2011). The basalt fiber reinforced polymer (BFRP) value of density, elasticity modulus, tensile strength, and elongation to fractre were $2,8 \mathrm{~g} /$ $\mathrm{cm}^{3}, 89 \mathrm{GPa}, 2,8 \mathrm{GPa}$, and 3,2\%, respectively (Colombo et al. 2012).

Recently, A great deal of investigations has been studied wooden reinforced with the FRP Among the others, Basterra et al. (2012), Nowak et al. (2013), Osmannezhad et al. (2014), McConnell (2015), Raftery and Kelly (2015), Schober et al. (2015), Brol and Wdowiak (2017), Brol et al. (2018), Zhou et al. 2018, Wdowiak and Brol (2019), Gaff et al. (2019), Wang et al. (2019), Zhou et al. (2019), Zhou et al. (2020), Wdowiak-Postulak (2021) have studied the FRP reinforcement under several test configurations such as different density, layer number, and loaded. On the bending moment resistance of T-type, two-pin dowel joints with reinforced basalt fiber woven fabric are not applied and it is considered that there is a deficiency in the literature. The BFRP with reinforced joints in frame-type furniture is a new research topic.

The aim of study is to determine the effects of wood species, wooden dowel species and fiber woven fabric types (BFRP and GFRP) on the bending moment resistance of the T-type joints, two-pin dowel joints.

\section{MATERİALS AND METHODS}

The woods of oak (Quercus petraea Liebl.), beech (Fagus orientalis Lipsk), chestnut (Castanea sativa Mill.), and Scotch pine (Pinus sylvestris Lipsky) were chosen randomly from timber merchants of Karabük in Turkey (Figure 1a). Special emphasis is given for the selection of the wood material. The test specimens were selected natural color uniformity, smoothness of fibers, absence of knots, heart uniformity, absence of reaction wood, and absence of fungal and insect damage. It has beeen paid attetion that the wood material used in experimental studies is not exposed to physical damage, mechanical impacts, or biological damage.

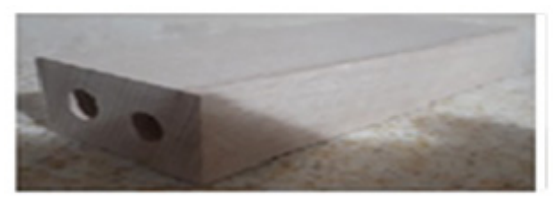

Beech

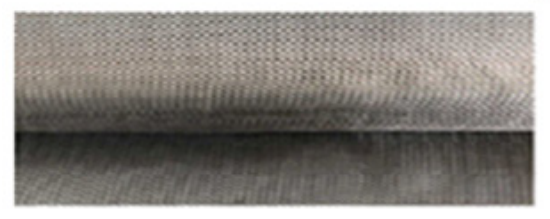

BFRP $\left(200 \mathrm{~g} / \mathrm{m}^{2}\right)$

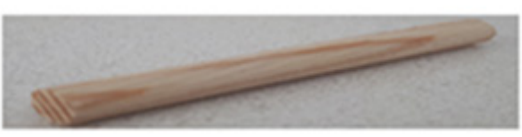

Scotch pine

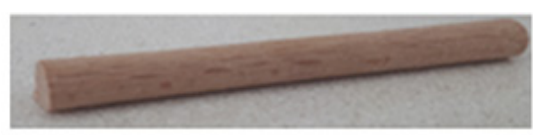

Beech

(a)

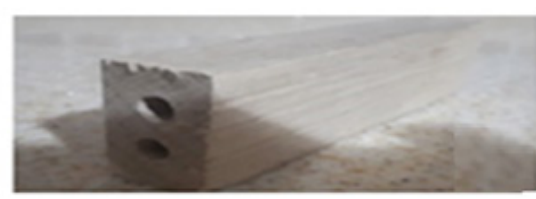

Oak

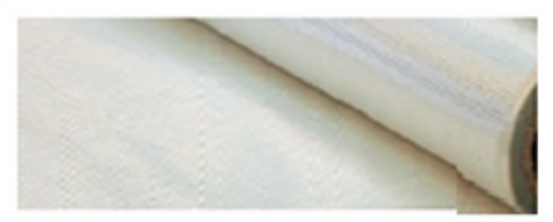

GFRP $\left(200 \mathrm{~g} / \mathrm{m}^{2}\right)$

(b)

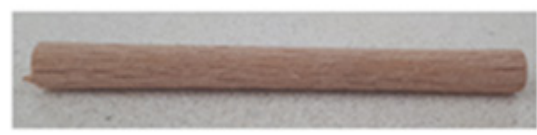

Chestnut

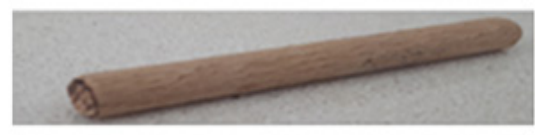

Oak

(c)

Figure 1: Materials used in experiments (a) wood species, (b) basalt and glass woven fabric, (c) wooden dowel species. 
Moisture contents (MC) and densities of the wooden materials were tested according to TS 2471 (1976) and TS 2472 (1976) standards, respectively.

Measured average densities were: oak $690\left(\mathrm{~kg} / \mathrm{m}^{3}\right)$, beech $670\left(\mathrm{~kg} / \mathrm{m}^{3}\right)$, average moisture contents were: oak $11,8 \%$, beech $11,5 \%$, respectviley. The two wood species were cut on boards of $25 \mathrm{~mm}$ thickness x 50 mm width.

Wooden dowel species were supplied from a local shop in timber enterprises in the Karabuk, Turkey. Dowels with threaded bodies having a diameter of $8 \mathrm{~mm}$, lengths of $40 \mathrm{~mm}$ and the moisture content of $8 \%$ to $12 \%$ was used in the experiments (Figure 1). Dowels were prepared from chestnut, oak, Scotch pine and beech woods. Measured average densities were: oak $690\left(\mathrm{~kg} / \mathrm{m}^{3}\right)$, beech $670\left(\mathrm{~kg} / \mathrm{m}^{3}\right)$, chestnut $570\left(\mathrm{~kg} / \mathrm{m}^{3}\right)$, Scotch pine $500\left(\mathrm{~kg} / \mathrm{m}^{3}\right)$, average moisture contents were: oak $11,8 \%$, beech $11,5 \%$, chestnut $10,2 \%$, Scotch pine $9,3 \%$, respectively.

The BFRP and GFRP for $200\left(\mathrm{~g} / \mathrm{m}^{2}\right)$ plain materials used in the study was obtained by Dost Chemical Industry Raw Material Industry and Trading Company (Turkey, Istanbul) (Figure 1c). The BFRP and GFRP were prepared by cutting to $100 \mathrm{~mm}$ in length and $50 \mathrm{~mm}$ in width.

The adhesives used in this test were polyvinyl acetate adhesive (PVAc-D4) which is commonly used in the wood industry and case type furniture manufacture (Kronen Furniture Glue Accessory Industrial Products Industry and Trade Ltd Co., Izmir, Turkey) and epoxy adhesive L285 resin + H285-hardener (Dost Chemical Industry Raw Material Industry and Trading Co., Istanbul Turkey). The technical parameters of the two adhesives are shown in Table 1.

Table 1: Technical data and characteristics of the adhesives.

\begin{tabular}{|c|c|c|}
\hline Technical Data & $\begin{array}{c}\text { Polyvinyl acetate } \\
\text { (PVAc-D4) }\end{array}$ & $\begin{array}{c}\text { Epoxy } \\
(\text { L285 resin+ H285 Hardener) }\end{array}$ \\
\hline Viscosity (mPas) & $15000-16000$ at $20^{\circ} \mathrm{C}$ & $600-900$ at $25^{\circ} \mathrm{C}$ \\
\hline Working time (min) & $35-40$ at $20^{\circ} \mathrm{C}$ & $45-240$ at $25^{\circ} \mathrm{C}$ \\
\hline Density $\left(\mathrm{g} / \mathrm{cm}^{3}\right)$ & 1,08 at $20^{\circ} \mathrm{C}$ & 1,21 at $25^{\circ} \mathrm{C}$ \\
\hline Solids content (\%) & 50 & - \\
\hline $\mathrm{pH}$ & 3,5 & - \\
\hline Main agent/Hardener Ratio (w/w) & $100 / 5$ & $100 / 50$ \\
\hline
\end{tabular}

\section{Preparation and construction of specimens}

The T-type, pin-dowel joints structure, comprising the rail and post members, as shown in Figure 2. Dimensions of the posting member and the rail were $150 \mathrm{~mm} \times 50 \mathrm{~mm} \times 25 \mathrm{~mm}$ and $125 \mathrm{~mm} \times 50 \mathrm{~mm} \times 25 \mathrm{~mm}$, respectively. Members were combined with each other with two wooden dowels with a nominal diameter of $8 \mathrm{~mm}$ and a length of $40 \mathrm{~mm}$. The dowels were produced from wood species measured $100 \mathrm{~mm}$ long by 11 $\mathrm{mm}$ wide by $11 \mathrm{~mm}$ thickness of wood pieces with using a dowel drawing machine. The distance between the centerlines of the two dowels were $20 \mathrm{~mm}$. Joints specimens were constructed of oak and beech. The rail and post members were drilled with a drilling machine. Depths of the dowel holes in both the post and the rail was $21 \mathrm{~mm}$. Then the holes in the member were cleaned with compressed air. All specimens were assembled with a polyvinyl acetate adhesive (PVAc-D4). The walls of the holes and the sides of the dowels were liberally coated with adhesive prior to insertion of the dowels. In all samples, a piece of wax paper was included between the two members to prevent any possibility of the members adhesion. Then, areas where BFRP and GFRP were to be placed were bonded with a blend of epoxy adhesive and hardener. Joint instances were left to dry for two days. Test samples are not reinforced, one layer and two surfaces reinforced with BFRP or GFRP in Figure 2. 

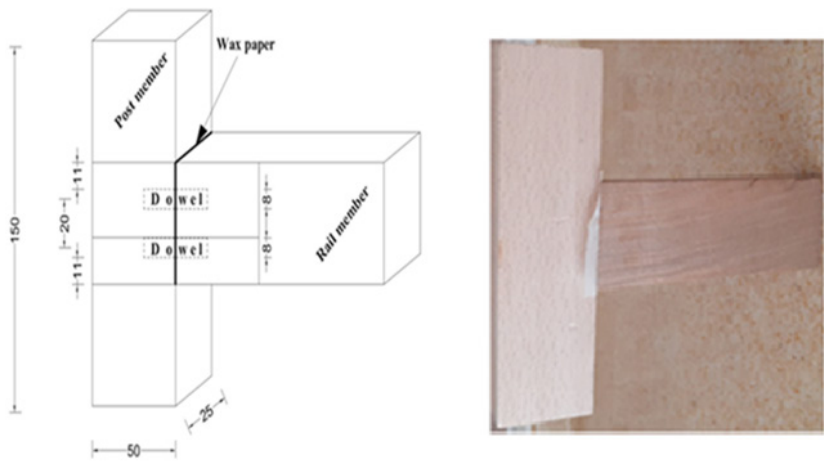

not reinforced
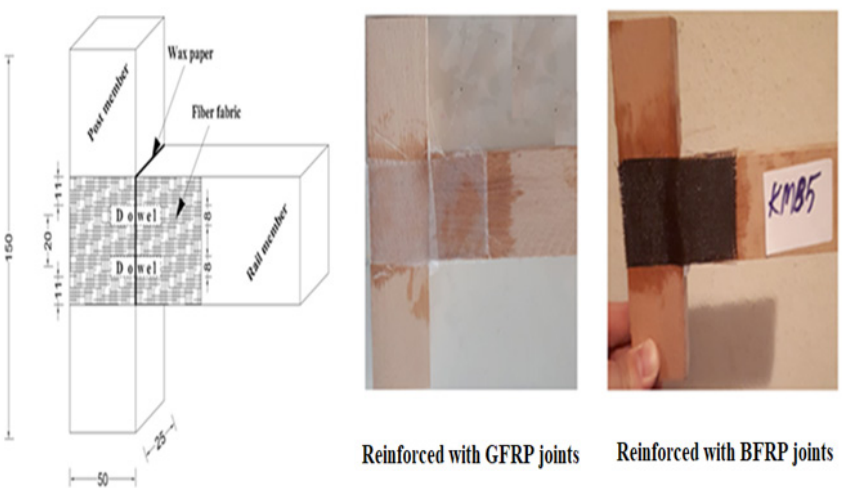

Reinforced with GFRP joints $\quad$ Reinforced with BFRP joints

Figure 2: Diagram showing the construction of T-type joints (dimensions in mm).

According to this, two wood species, four wooden dowel species, and two fiber woven fabric types (BFRP, GFRP, and control), and 5 samples of each material $(2 \times 4 \times 3 \times 5)$ were the variables, totally a number of 120 samples were constructed in this research. Prior to testing, all samples were conditioned in a humidity chamber controlled at $20{ }^{\circ} \mathrm{C} \pm 2{ }^{\circ} \mathrm{C}$ and $65 \% \pm 5 \%$ relative humidity (RH) for two weeks.

\section{Method of testing}

All tests were conducted on a SHIMADZU universal test machine (SHIMADZU Corp., Sydney, Australia). Specimens were held for testing as shown in Figure 3. In all of the T-type, two pin dowel joints tested on a SHIMADZU universal test machine (SHIMADZU Corp., Sydney, Australia) at a loading rate of $8 \mathrm{~mm} \cdot \mathrm{min}^{-1}$. Loads were applied to the stump $125 \mathrm{~mm}$ in front of the rail. Load-displacement curves of tested joints and their failure modes were recorded. The bending moment resistance values were found using as follows (Equation 1).

$$
M=F \times L
$$

Where $M$ is the bending moment resistance $(\mathrm{N} \cdot \mathrm{m}), F$ is the ultimate applied force $(\mathrm{N})$ and $L$ is the moment $\operatorname{arm}(\mathrm{m})$. 

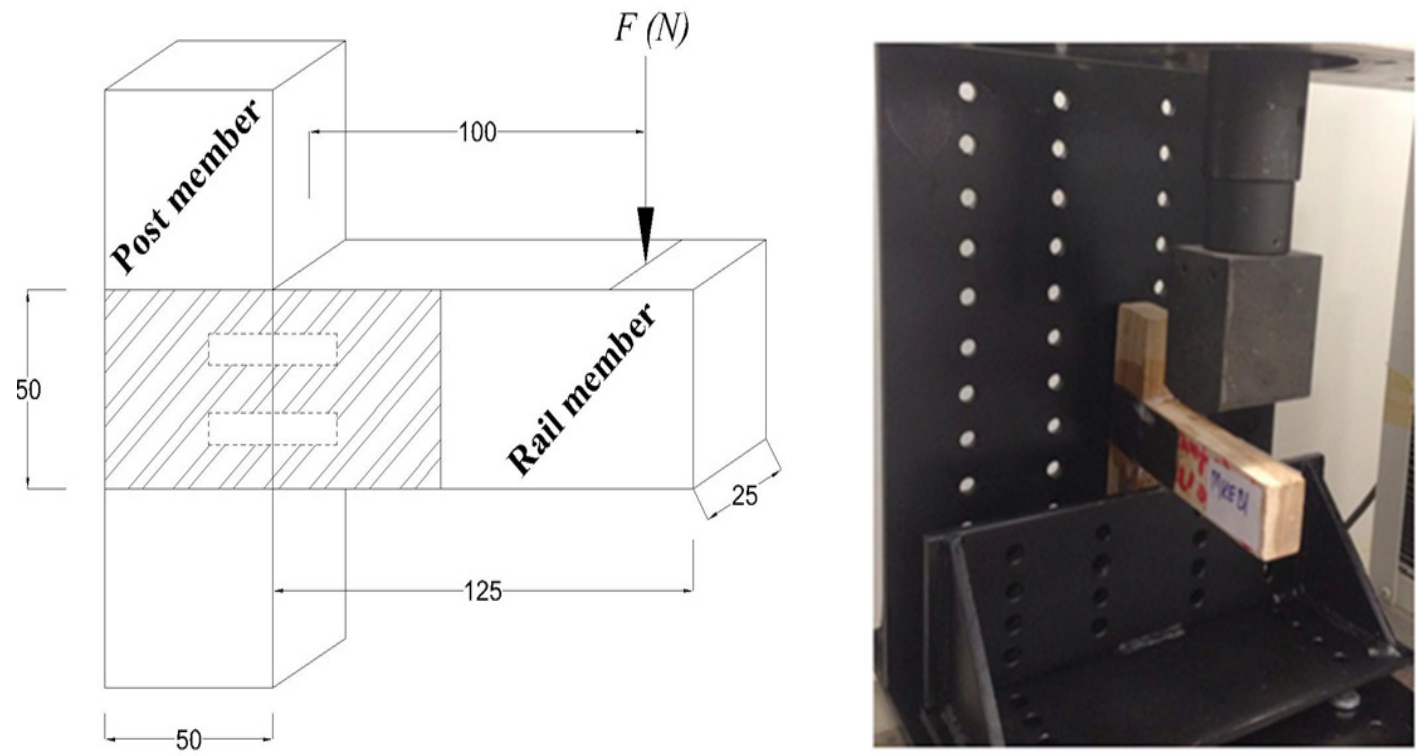

Figure 3: Way of support and loading the specimens of the corner joints.

\section{Statistical analyses}

A two way analysis of variance (ANOVA) statistical analysis was used applying the statistical package IBM SPSS 22. The effects of the wood species, the wooden dowel species and the fiber woven fabric types on the bending moment resistance were determined by analysis of variance $(\alpha=0,05)$. The bending moment resistance influence levels of the factors were determined by applying the Tukey Homogeneity Test to the influential factors within the groups and among the groups.

\section{RESULTS AND DİSCUSSİON}

The mean values bending moment resistance under compression of T-type joints with their standard deviation and coefficients of variation were presented in Table 2 .

According to multiple comparisons on the bending moment capacities, the highest bending moment resistance value was obtained from oak wooden jointed with an oak dowel and reinforced with BFRP (157,37 $\mathrm{N} \cdot \mathrm{m}$ ), while the lowest value was acquired in beech wooden with Scotch pine dowel and not reinforced (control) $(55,94 \mathrm{~N} \cdot \mathrm{m})$. 
Table 2: Mean values of the bending moment resistance of joints with their coefficients of variation.

\begin{tabular}{|c|c|c|c|c|c|}
\hline Wood Species & Wooden Dowel Species & Fiber Woven Fabric Types & $\begin{array}{l}\text { Mean } \\
(\mathrm{N} \cdot \mathrm{m})\end{array}$ & SD & $\begin{array}{c}\text { COV } \\
(\%)\end{array}$ \\
\hline \multirow{12}{*}{ Beech } & \multirow{3}{*}{ Chestnut } & Control (No-SMT) & 67,78 & 6,68 & 9,86 \\
\hline & & GFRP & 92,97 & 2,70 & 2,90 \\
\hline & & BFRP & 104,31 & 6,81 & 6,53 \\
\hline & \multirow{3}{*}{ Beech } & Control (No-SMT) & 75,51 & 3,65 & 4,83 \\
\hline & & GFRP & 92,94 & 7,49 & 8,06 \\
\hline & & BFRP & 134,09 & 9,85 & 7,35 \\
\hline & \multirow{3}{*}{ Oak } & Control (No-SMT) & 84,41 & 2,84 & 3,36 \\
\hline & & GFRP & 114,41 & 6,53 & 5,71 \\
\hline & & BFRP & 149,54 & 5,88 & 3,93 \\
\hline & \multirow{3}{*}{ Scotch pine } & Control (No-SMT) & 55,94 & 2,86 & 5,11 \\
\hline & & GFRP & 85,92 & 7,68 & 8,94 \\
\hline & & BFRP & 99,19 & 7,61 & 7,67 \\
\hline \multirow{12}{*}{ Oak } & \multirow{3}{*}{ Chestnut } & Control (No-SMT) & 69,26 & 8,27 & 11,94 \\
\hline & & GFRP & 88,78 & 5,64 & 6,35 \\
\hline & & BFRP & 113,22 & 6,88 & 6,08 \\
\hline & \multirow{3}{*}{ Beech } & Control (No-SMT) & 75,69 & 5,18 & 6,84 \\
\hline & & GFRP & 105,53 & 8,67 & 8,22 \\
\hline & & BFRP & 132,12 & 7,18 & 5,43 \\
\hline & \multirow{3}{*}{ Oak } & Control (No-SMT) & 83,28 & 2,56 & 3,07 \\
\hline & & GFRP & 109,78 & 5,69 & 5,18 \\
\hline & & BFRP & 157,37 & 4,32 & 2,75 \\
\hline & \multirow{3}{*}{ Scotch pine } & Control (No-SMT) & 59,17 & 4,65 & 7,86 \\
\hline & & GFRP & 79,85 & 6,37 & 7,98 \\
\hline & & BFRP & 109,59 & 5,03 & 4,59 \\
\hline
\end{tabular}

SD: Standart deviation, COV: Coefficient of variation, SMT: Supporting material type.

The results of the multi-way ANOVA analysis of the wood species, the wooden dowel species, and type of fiber reinforced polymers on the bending moment resistance of the T-type, two pin dowel joints under the compression load were given in the Table 3.

Table 3: Summary of the ANOVA results for moment resistance.

\begin{tabular}{|c|c|c|c|c|c|}
\hline Source & df & Sum of Square & $\begin{array}{c}\text { Mean } \\
\text { Square }\end{array}$ & F & Sig. \\
\hline Corrected Model & 23 & 84342,048 & 3667,046 & 95,551 & 0,000 \\
\hline Intercept & 1 & 1136504,907 & $\begin{array}{c}1136504,9 \\
0\end{array}$ & 29613,664 & 0,000 \\
\hline Wood Species (A) & 1 & 208,587 & 208,587 & 5,435 & 0,022 \\
\hline Wooden Dowel Species (B) & 3 & 21557,592 & 7185,864 & 187,241 & 0,000 \\
\hline $\begin{array}{c}\text { Fiber Woven Fabric Types } \\
(\mathrm{C})\end{array}$ & 2 & 58761,030 & 29380,515 & 765,562 & 0,000 \\
\hline $\mathrm{A} \times \mathrm{B}$ & 3 & 44,305 & 14,768 & 0,385 & 0,764 \\
\hline $\mathrm{A} \times \mathrm{C}$ & 2 & 238,629 & 119,315 & 3,109 & 0,049 \\
\hline $\mathrm{B} \times \mathrm{C}$ & 6 & 2670,815 & 445,136 & 11,599 & 0,000 \\
\hline $\mathrm{A} \times \mathrm{B} \times \mathrm{C}$ & 6 & 861,090 & 143,515 & 3,740 & 0,002 \\
\hline Error & 96 & 3684,261 & 38,378 & & \\
\hline Total & 120 & 1224531,216 & & & \\
\hline Corrected Total & 119 & 88026,309 & & & \\
\hline
\end{tabular}

R Squared $=0,958$ (Adjusted R Squared $=0,948)$ df: Degrees of Freedom. 
According to the analysis of variance as presented in Table 3, the effects of the main factors including the wood species (A), the wooden dowel species (B), and the fiber woven fabric types (C) were found to be statistically significant, while wood species $\times$ wooden dowel species $(A \times B)$ was insignificant at the level of 0,05 . Two-way interactions of wood species $\times$ fiber woven fabric types $(A \times C)$, and wooden dowel species $\times$ fiber woven fabric types $(B \times C)$ were statistically significant at the level of 0,05 . Three factor interactions of wood species $\times$ wooden dowel species $\times$ fiber woven fabric types $(A \times B \times C)$ were also statistically insignificant $(\mathrm{p} \leq 0,05)$. Tukey test was carried out in order to determine these differences. The bending moment resistance means according to independent effects of test variables were given in Table 4.

Table 4: The results from the Tukey's test for independent effects of test variables.

\begin{tabular}{|c|c|c|c|c|}
\hline \multicolumn{2}{|c|}{ Source } & $\begin{array}{c}\text { Bending moment } \\
\text { capacity } \\
(\mathrm{N} \cdot \mathrm{m})\end{array}$ & SD & HG \\
\hline \multirow{2}{*}{ Wood species } & Oak & 98,64 & 5,88 & A \\
\cline { 2 - 5 } & Beech & 96,00 & 5,87 & B \\
\hline \multirow{4}{*}{ Wooden dowel species } & Oak & 116,46 & 4,64 & A \\
\cline { 2 - 5 } & Beech & 102,65 & 7,00 & B \\
\cline { 2 - 5 } & Chestnut & 88,56 & 6,16 & C \\
\cline { 2 - 5 } & Scotch pine & 81,61 & 5,70 & D \\
\hline \multirow{3}{*}{ Fiber woven fabric types } & BFRP & 124,93 & 6,70 & A \\
\cline { 2 - 5 } & GFRP & 96,27 & 6,35 & B \\
\cline { 2 - 5 } & Control & 70,75 & 4,59 & C \\
\hline
\end{tabular}

SD: Standart deviation, HG: Homogeneity groups.

When the comparison results of wood species were examined, it was seen that the highest bending moment resistance value was obtained for oak $(98,64 \mathrm{~N} \cdot \mathrm{m})$. The bending moment resistance of beech wood was much lower. The oak wood was $3 \%$ stronger than the beech wood (Table 4). The density of oak wood was higher than the density of the beech wood used in the experiments.

For the wooden dowel species, the oak dowel showed significantly higher the bending moment resistance value than other dowels (Table 4). The bending moment resistance value of oak was approximately $13 \%, 32$ $\%$ and $43 \%$ higher than for joints constructed with beech, chestnut and Scotch pine, respectively. The situation with the species of lumber used for dowels can explain with the structural properties of the materials. The reasons for these may be based on the density of wooden materials. As a general rule, mechanical properties increase as the density of solid wood material increases. There is an increasing-linear relationship between bending strength, modulus of elasticity and shock resistance and density. In previous studies, many researchers have identified this relationship (Kollmann and Cote 1968, Bozkurt and Erdin 1995, Bektaş et al. 2002, Bal and Bektaş 2018).

According to fiber woven fabric, the highest bending moment resistance value were obtained in basalt fiber woven fabric (BFRP) $(124,93 \mathrm{~N} \cdot \mathrm{m})$, and the lowest was in control samples $(70,75 \mathrm{~N} \cdot \mathrm{m})$. The mean bending moment resistance of joints with BFRP was $30 \%$ and $77 \%$ higher than joints with GFRP, and not reinforced joints (control), respectively.

Dorigato and Pegoretti (2012) explained that the basalt fibers have exhibit mechanical properties fully comparable with those of glass fibers, the elastic modulus of basalt and the tensile strength were greater than glass fibers. Chairman and Kumaresh Babu (2013) obtained that compressive and tensile ultimate strength of BFRP laminates are higher than GFRP laminates of about $43 \%$ and $23 \%$, respectively. Borri et al. (2013a) investigated flax and basalt FRP strengthened low-grade (bending strength of 18,4 MPa) and high-grade (bending strength of $41,3 \mathrm{MPa}$ ) wood beams. The results showed an increase of bending strength of $38,6 \%$ and $65,8 \%$, This study concluded that both BFRP and FFRP provided the beams with higher strength and better ductile behavior. Similar results can be found in another research by Borri et al. (2013b) for flax and basalt FRP. André and Johnsson (2010) applied FFRP and GFRP with similar fabric density (i.e., $230 \mathrm{~g} / \mathrm{m}^{2}$ for flax and $250 \mathrm{~g} / \mathrm{m}^{2}$ for glass) perpendicular to grain on wood beams. It is reported that the maximum bending load of 
the entire specimen strengthened with GFRP $(45,1 \mathrm{kN})$ was $23 \%$ higher than that one strengthened with FFRP $(36,0 \mathrm{kN})$. McConnell et al. (2015) in their investigations into the reinforcement of wooden beams with BFRP tensile basalt fibres noted an increased load capacity and rigidity of $28 \%$ and $8,7 \%$, respectively. Monaldo et al. (2019) explained that beams reinforced with BFRP have a bending ultimate load higher of by about $20 \%$ than the case of GFRP.

Wdowiak-Postulak (2021) found that the load carrying capacity of beams reinforced with basalt fibre was higher by, respectively, $13 \%$ and $20 \%$ than that of reference beams, while their rigidity improved by, respectively, $9,99 \%$ and $17,13 \%$.

The most popularly used high-strength fibers are carbon fiber, glass fiber, and basalt fiber. In comparison to other fibers, basalt fiber has superior characteristics, that is, high strength to weight ratio, excellent ductility and durability, high thermal resistance, chemical resistance, good corrosion resistance, fire resistance, high temperature resistance, high performance in terms of strength, and cost-effectiveness (Fiore et al. 2011, Wang et al. 2013), as well as the lower potential cost with respect to other fibre-reinforced polymer (FRP) materials (Fiore et al. 2015).

The cost of elements used in traditional reinforcement methods is low compared to that of FRP materials. But in the long run, elements such as bolts, nails, etc. may not be effective on timber. Therefore, it is more convenient to use FRP materials instead of traditional reinforcement methods as they require maintenance and repair over time and have low durability.

\section{Failure modes}

After testing, all connections were visually inspected in order to identify the failure mode of the dowels. In the bending moment resistance test of T-type two pin dowel joints construction with Beech and Oak wood in not reinforced samples deformations as in Figure 4 were observed. While there was no deformation in the wooden members, bending deformation in the dowel used for the joint was observed. For all of the joint types, failures initially occurred as opening at the inner face of joints when those joints were subjected to bending moment. The width of the gap between the rail and the post was measured to obtain the degree of decay of the dowel joints. As result, it was seen that the highest rate of the gap was in Oak wood + Beech dowel test samples (Figure 4a2). Oak wood+Chestnut dowel, Beech wood+Beech dowel, Beech wood+Oak dowel, samples followed respectively (Figure 4a3, Figure 4b2, Figure 4b1). Other samples were observed lower. It can be said that the gap rate in other examples is lower.

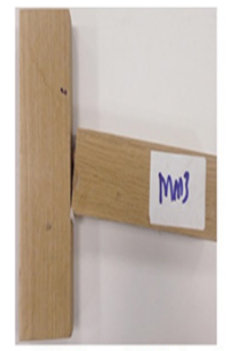

al) Oak wood + Oak dowel

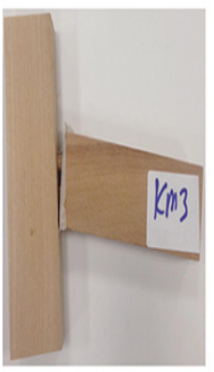

bl) Beech wood + Oak dowel

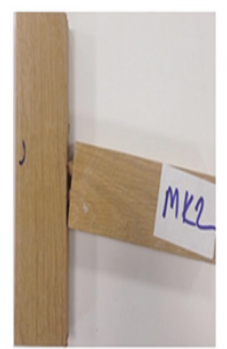

a2)Oak wood+Beech dowel

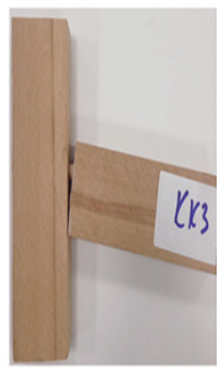

b2) Beech wood + Beech dowel
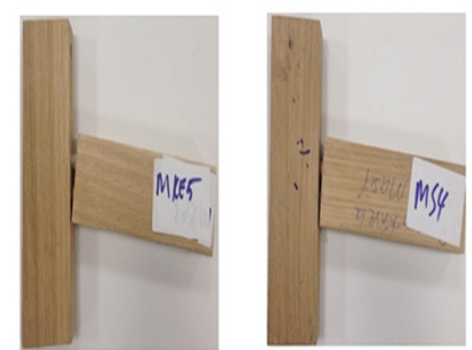

a3) Oak wood +Chestnut dowel a4) Oak wood + Scotch pine dowel
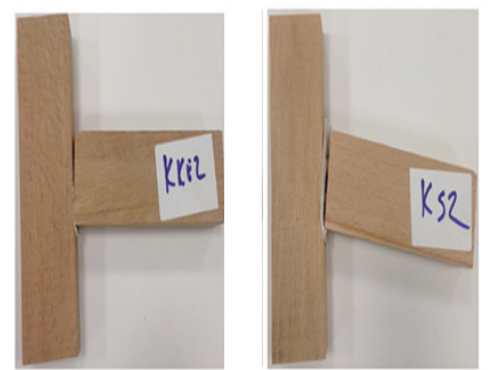

b3) Beech wood + Chestnut dowel b4)Beech wood + Scotch pine dowel

Figure 4: Mode of T-type, two pins dowel joint failure not reinforced. 
The deformations of dowel joints the reinforced with GFRP strengthened are shown in Figure 5. According to the reinforced joints, glass fiber woven fabric has prevented cracking. It was observed for all of the joint types, failures not occurred as opening at the inner face of joints when those joints were subjected to bending moment. The gaps were much shorter than the not reinforced samples. For the samples of the Oak wood+Chestnut dowel+GFRP, cracks occurred on the inner face of the face members (Figure 5c). The deformations of dowel joints the reinforced with GFRP strengthened are than not reinforced samples. It is seen that the deformation of the dowel joints reinforced with GFRP is less than the samples un reinforcement.

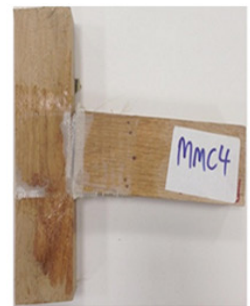

cl) Oak wood+Oak dowel+GF

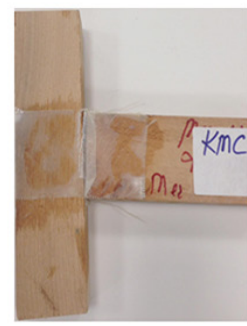

dl) Beech wood + Oak dowel + GFRP

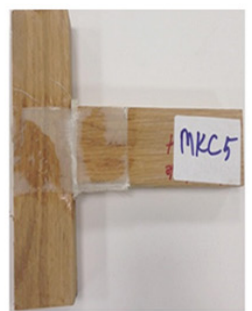

c2) Oak wood+Beech wood+GFRP

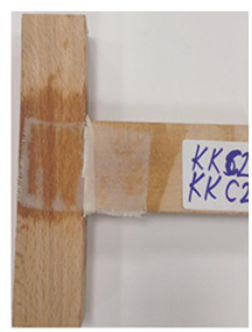

d2)Beech wood+Beech dowel +GFRP

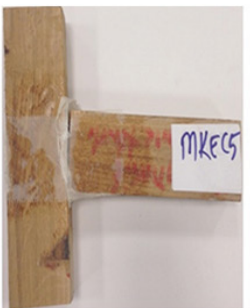

3) Oak wood+Chestnut dowel+GFR

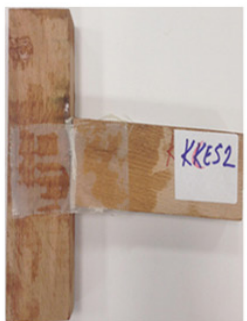

d3)Beech wood + Chestnut dowel + GFRP

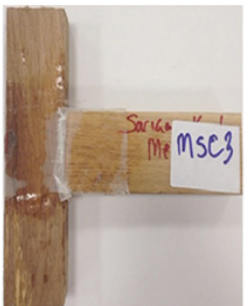

4) Oak wood + Scotch pine dowel+GFRP

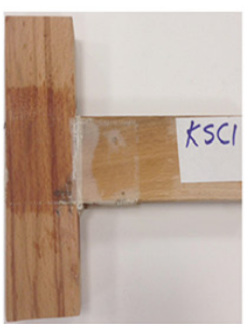

d4)Beech wood + Scotch pine dowel +GFRP

Figure 5: Mode of T-type, two pin dowel joint failure reinforced with GFRP.

The deformation of the T- type two pin dowel joints with inforced by basalt woven fabric under bending strength test is shown in Figure 6. According to test results, the failures that occurred as a split of particleboard in both the face and butt members. In the joints of the test samples reinforced with BFRP, failures have occured on the outer face of the basalt woven fiber fabric. In all of the samples the beech joints reinforced with BFRP (Figure 6f), the failures are almost identical. For the samples of constructed with oak wooden, it is seen that the failures occurred as a result of cracking at the junction of the middle of the basalt woven fabric are more in the Oak wood+Oak dowel+BFRP (Figure 6f1) and Oak wood+Chestnut dowel+BFRP (Figure 6f3) samples.
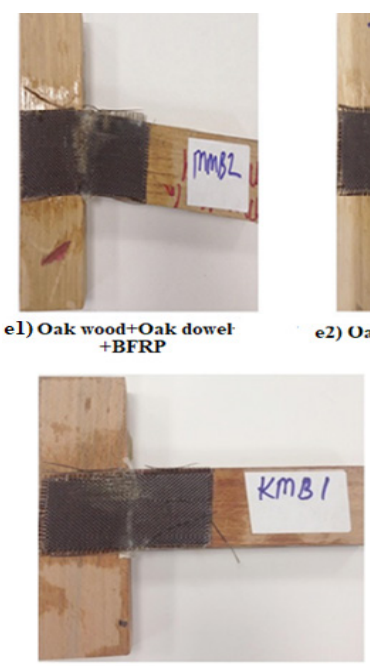

f1) Beech wood+Oak dowel+BFRP

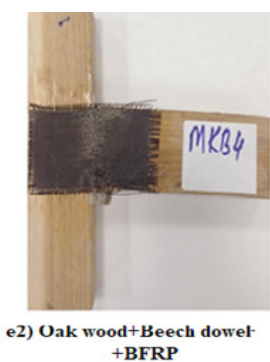

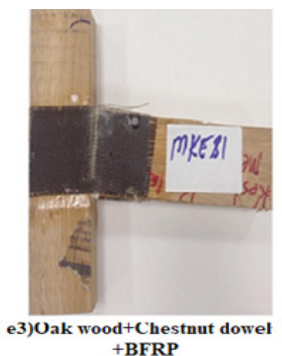

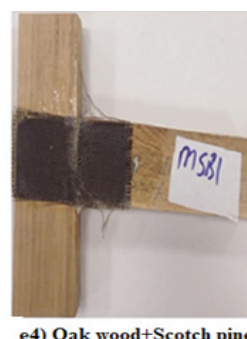

e4) Oak wood + Scotch pin dowel+BFRP

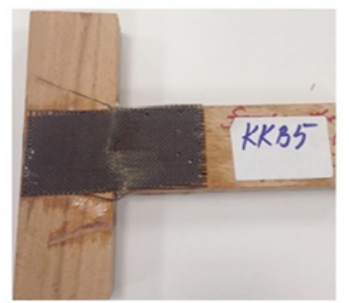

f2) Beech wood+Oak dowel+BFR

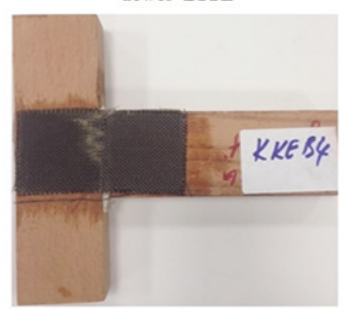

f3) Beech wood+Chestnut dowel+BFRP

Figure 6: Mode of T-type, two pin dowel joint failure reinforced with BFRP. 


\section{CONCLUSIONS}

Wood material is among the most widely used building materials due to the fact that it is renewable, low cost, natural, easy to recycle and aesthetic. It is known that one of the most important advantages of reinforcement with basalt and glass fabrics is to strengthen and repair the wood material. Although the application of these methods brings a cost burden to the user, it increases the useful life of the wood structure. For this aim, it is an ideal reinforcement element for wood materials since it has a high degree of hardness and higher strength compared to its light weight and it is a non-abrasive corrosion resistant flexible material which ensures the reduction of long-term maintenance costs and provides fast installation on site. Also, these materials demonstrate high durability in corrosive environments thanks to their high resistance to fatigue. The production of reinforced wood materials with high economic value and their increasing use can benefit economically.

The bending moment resistance of T-type, two-pin dowel joints constructed four wooden dowel species and reinforced with basalt fiber woven fabric and glass fiber woven fabric was investigated. Experimental results indicated that traditional glued Oak dowel joints yielded the highest bending moment resistance among Beech dowel, Chestnut dowel and Scotch pine dowel joints. Scotch pine dowel joints had the lowest bending moment resistance among the joints evaluated. The mean comparison showed that Beech dowel joints could produce a higher bending moment resistance than Chestnut dowel joints. The bending moment resistance value of reinforced joints (for GFRP and BFRP joints, respectively) were $30 \%$ and $77 \%$ higher than not reinforced joints.

Researchers could be provide a range of optimum values, for the parameters (wood species, four different wooden dowel species, fiber woven fabric types) affecting frame furniture joint bending moment resistance and this colud be helpful for engineering design of furniture structures. Future studies will have to investigate the bending moment resistance of L-shaped two-pin dowel joints reinforced with different FRP materials.

\section{REFERENCES}

André, A.; Johnsson, H. 2010. Flax fiber-reinforced glued-laminated timber in tension perpendicular to the grain: experimental study and probabilistic analysis. J Mater Civ Eng 22 (9): 827-835. https://doi.org/10.1061/(ASCE)MT.1943-5533.0000070

Bal, B.C.; Bektaş, İ. 2018. A research on the determination of the relationship between density and some mechanical properties of wood. Mamad 1(2): 51-61. https://doi.org/10.33725/mamad.467353

Basterra, L.A.; Acuna, L.; Casado, M.; Lopez, G; Bueno, A. 2012. Strength testing of Poplar duo beams, Populus x euramericana (Dode) Guinier cv. I-214, with fibre reinforcement. Constr Build Mater 36: 90-96. https://doi.org/10.1016/j.conbuildmat.2012.05.001

Bektaş, İ.; Güler, C.; Baştürk, M.A. 2002. Principal mechanical properties of eastern beech wood (Fagus orientalis L.) naturally grown in Andırın northeastern mediterranean region of Turkey. Turk J Agric For 26:147-154. https://journals.tubitak.gov.tr/agriculture/issues/tar-02-26-3/tar-26-3-6-0107-1.pdf

Brol, J.; Wdowiak, A. 2017. The use of glass and aramid fibres for the strengthening of timber structures. Annals of Warsaw University of Life Sciences-SGGW, Forestry and Wood Technology 100: 128-138. http://wtd.sggw.pl/pix/files/Annals\%20of\%20WULS\%20No\%20100\%202017.pdf

Brol, J.; Nowak, T.; Wdowiak, A. 2018. Numerical Analysis and Modelling of Timber Elements Strengthened with FRP Materials. Annals of Warsaw University of Life Sciences-SGGW, Forestry and Wood Technology 104: 274-282. http://wtd.sggw.pl/pix/files/Annals\%20of\%20WULS\%20tom\%20104.pdf

Borri, A.; Corradi, M.; Speranzini, E. 2013a. Reinforcement of wood with natural fibers. Compos $B$ Eng 53: 1-8. https://doi.org/10.1016/j.compositesb.2013.04.039

Borri, A.; Corradi, M.; Speranzini, E. 2013b. Bending tests on natural fiber reinforced fir wooden elements. Adv Mater Res 778: 537-544. https://doi.org/10.4028/www.scientific.net/AMR.778.537 
Bozkurt, Y.; Erdin, N. 1995. The relationship between density and mechanical properties of woods. Forestist 45(2): 11-34. https://forestist.org/en/the-relationship-between-density-and-mechanical-properties-of-woods-161456

Chairman, C.A.; Kumaresh Babu, S.P. 2013. Mechanical and abrasive wear behavior of glass and basalt fabric-reinforced epoxy composites. J Appl Polym Sci 130(1): 120-130. https://doi.org/10.1002/app.39154

Chen, M.; Li, X.M.; Lyu, J.H. 2018. Influence of dowel diameter and curing time on strength of double dowel joint. Wood Res-Slovakia 63(4): 591-598. http://www.woodresearch.sk/wr/201804/06.pdf

Colombo, C.; Vergani, L.; Burman, M. 2012. Static and fatgiue characterization of new basalt fibre reinforced composites. Compos Struct 94(3): 1165-1174. http://dx.doi.org/10.1016/j.compstruct.2011.10.007

Dorigato, A.; Pegoretti, A. 2012. Fatigue resistance of basalt fibers-reinforced laminates. J Compos Mater 46(15): 1773-1785. https://doi.org/10.1177/0021998311425620

Fiore, V.; Di Bella, G.; Valenza, A. 2011. Glass-basalt/epoxy hybrid composites for marine applications. Mater Des 32(4): 2091-2099. https://doi.org/10.1016/j.matdes.2010.11.043

Fiore, V.; Scalici, T.; Di Bella, G.; Valenza, A. 2015. A review on basalt fibre and its composites. Compos B Eng 74: 74-94. https://doi.org/10.1016/j.compositesb.2014.12.034

Gaff, M.; Kačík, F.; Gašparík, M. 2019. Impact of thermal modification on the chemical changes and impact bending strength of European oak and Norway spruce wood. Compos Struct 216: 80-88. https://doi.org/10.1016/j.compstruct.2019.02.091

Hao, J.; Xu, L.; Wu, X.; Li, X. 2020. Analysis and modeling of the dowel connection in wood T type joint for optimal performance. Compos Struct 253: 112754. https://doi.org/10.1016/j.compstruct.2020.112754

Kollmann, F.; Cote, W.A. 1968. Principles of wood science and technology. Springer Verlag.

McConnell, E.; McPolin, D.; Taylor, S. 2015. Post-tensioning glulam timber beams with basalt FRP tendons. Constr Mater 168(5): 232-240. https://doi.org/10.1680/coma.14.00032

Monaldo, E.; Nerilli, F.; Vairo, G. 2019. Basalt-based fiber-reinforced materials and structural applications in civil engineering. Compos Struct 214: 246-263. https://doi.org/10.1016/j.compstruct.2019.02.002

Nowak, T.P.; Jasienko, J.; Czepizak, D. 2013. Experimental tests and numerical analysis of historic bent timber elements reinforced with CFRP strips. Constr Build Mater 40: 197-206. https://dx.doi.org/10.1016/j. conbuildmat.2012.09.106

Osmannezhad, S.; Faezipour, M.; Ebrahimi, G. 2014. Effects of GFRP on bending strength of glulam made of poplar (Populus deltoids) and beech (Fagus orientalis). Constr Build Mater 51: 34-39. https://dx.doi.org/10.1016/j.conbuildmat.2013.10.035

Raftery, G.M.; Kelly, F. 2015. Basalt FRP rods for reinforcement and repair of timber. Compos. Part B Eng 70: 9-19. https://doi.org/10.1016/j.compositesb.2014.10.036

Schober, K.U.; Harte, A.M.; Kliger, R.; Jockwer, R.; Xu, Q.; Chen J.F. 2015. FRP reinforcement of timber structures. Constr Build Mater 97: 106-118. https://doi.org/10.1016/j.compstruct.2019.02.091

Sim, J. 2001. Static and dynamics analysis of strengthening effect of glass FRP for bridge deck plate. Tech Res Report submitted to Hanyang University.

TS. 1976. Wood - Determination of Moisture Content for Physical and Mechanical Tests. TS 1976. 2471. TSE: Ankara, Turkey. https://intweb.tse.org.tr/

TS 1976. Wood - Determination of Density for Physical and Mechanical Tests. TS 1976. 2472. TSE: Ankara, Turkey. https://intweb.tse.org.tr/ 
Uysal, M.; Haviarova, E. 2018. Estimating design values for two-pin moment resisting dowel joints with lower tolerance limit approach. Bioresources 13(3): 5241-5253. https://ojs.cnr.ncsu.edu/index.php/BioRes/article/view/BioRes_13_3_5241_Uysal_Design_Values_Dowel_Joints_Tolerance/6146

Vassiliou, V.; Barboutis, I.; Kamperidou, V. 2016. Strength of corner and middle joints of upholstered furniture frames constructed with black locust and beech wood. Wood Res-Slovakıa 61(3): 495-504. http://www.woodresearch.sk/wr/201603/15.pdf

Wdowiak, A.; Brol, J. 2019. Effectiveness of reinforcing bent non-uniform pre-stressed glulam beams with basalt fibre reinforced polymers rods. Materials 12: 3141. https://doi.org/10.3390/ma12193141

Wdowiak-Postulak, A. 2021. Basalt fibre reinforcement of bent heterogeneous glued laminated beams. Materials 14: 51. https://dx.doi.org/10.3390/ma14010051

Wang, X.; Wu, Z.; Wu, G.; Zhu, H.; Zen, F. 2013. Enhancement of basalt FRP by hybridization for longspan cablestayed bridge. Compos B Eng 44(1): 184-192. https://doi.org/10.1016/j.compositesb.2012.06.001

Wang, B.; Bachtiar, E.V.; Yan, L.; Kasal, B.; Fiore, V. 2019. Flax; Basalt; E-Glass frp and their hybrid FRP strengthened wood beams: an experimental study. Polym 11(8): 1-16. https://doi.org/10.3390/ polym 11081255

Yerlikaya, N.C.; Aktas, A. 2013. Enhancement of t-joints of spruce wood reinforced by using glass-fiber composite laminate. Scientific Research And Essays 8 (13): 515-523. https://academicjournals.org/journal/ SRE/article-abstract/45F6D7432647

Záborský, V.; Sikora, A.; Gaff, M.; Kašičková, V.; Borůvka, V. 2018. Effect of selected factors on stiffness of dowel joints. Bioresources 13(3): 5416-5431. https://bioresources.cnr.ncsu.edu/resources/effects-of-selected-factors-on-spruce-dowel-joint-stiffness/

Zhang, J.; Li, G.; Sellers Jr., T. 2003. Bending fatigue life of two-pin dowel joints in furniture grade pine plywood. For Prod J 53 (9): 33-39.

Zhou, A.; Chow, C.L.; Lau, D. 2018. Structural behavior of GFRP reinforced concrete columns under the influence of chloride at casting and service stages. Compos Part B Eng 136: 1-9. https://doi.org/10.1016/j. compositesb.2017.10.011

Zhou, A.; Chow, C.L.; Lau, D. 2019. Structural performance of FRP confined seawater concrete columns under chloride environment. Compos Struct 216: 12-19. https://doi.org/10.1016/j.compstruct.2019.02.058

Zhou, A.; Chow, C.L.; Lau, D. 2020. Interfacial performance of aramid, basalt and carbon fiber reinforced polymer bonded concrete exposed to high temperature. Compos Part A Appl Sci Manuf 131: 105802. https://doi.org/10.1016/j.compositesa.2020.105802 